\title{
Microbial Gibberellins Impact on Zea mays (L.) Plants under Different Levels of Water Salinity
}

\author{
M. H. Mohamed ${ }^{1}$ and Ghada A. Mahmoud ${ }^{{ }^{*}}$ \\ ${ }^{1}$ Water Requirement and Field Irrigation Research Department, SWERI, ARC, 12112 , \\ Egypt \\ ${ }^{2}$ Botany and Microbiology Department, Faculty of Science, Assiut University, Assiut \\ 71516, Egypt
}

\begin{abstract}
$\mathbf{T}$
HESE days green advancements of phytohormones have a critical place in industrial food process displace the chemical manufacturing which causes genuine dangers by gathered in the environment, from these hormones; gibberellin has an industrial significance as it's a plant development controller hormone. Fungi produced several important substances with biological impact; from these substance plant hormones production involves great interest in agriculture. From different fungal isolates tested for gibberellins production, Fusarium oxysporum represented as a hopefulfungus for microbial gibberellin generation conducted $268.9 \pm 6.27 \mathrm{mg} / \mathrm{l}$ gibberellic acid with productivity rate $38.42 \mathrm{mg} / \mathrm{l} /$ day with succeeded capacity to apply in the field. In vivo application of microbial gibberellic acid occurred in pot experiment on Zea mays (L.) plants under water salinity stress. Synergetic development in maize plants exhibited with expanding microbial gibberellin concentrations until $150 \mathrm{ppm}$ under water salinity stress and then no huge diverse was cleared.Increasing in plant weight and height observed in compared to the non-treated plants.
\end{abstract}

Keywords: Phytohormones, Fusarium, Fungi, Salinity stress

\section{Introduction}

Fungi produced a critical group of natural bioactive compounds (secondary metabolites) (Quang et al., 2014), gibberellins represent small molecules of a large group of tetra-cyclic diterpenoid carboxylic acids, defined entgibberellane carbon skeleton. Gibberellins were identified first as in 1930s as phytohormones depends on an high-growth rice seedling due to infections by Fusarium fujikuroi (teleomorph Gibberella fujikuroi) a pathogenic rice fungus. There are 136 known gibberellins types produced by fungi, plants and even bacteria only GA1, GA3, GA4 and GA7 are prominent bioactive (Cross et al., 1959 and Davies, 2004). Gibberellic acid produced in elevated levels by fungi (Gibberella fujikuroi) compared to plants (Hedden et al., 2001).

Plant hormones assume a basic job in plant development and improvement, for example, seed germination, stem extension, blooming and fruit advancement. Gibberellins help plants to change their physiology to the ecological changes in quick response and adapt to fluctuating environmental conditions to meet the requests aganist expanding of food demand especially over the most recent couple of years (Olszewski et al., 2002; Fahad et al., 2014 and Hussain et al., 2014). Most familiar producer genera of gibberellins were Penicillium, Fusarium and Aspergillus (Tansakul et al. 2014). Gibberellins hormones combined by fungal strains such as Fusarium sacchari, F. konzum, F. glutinans, Aspergillus fumigatus, Penicillium janthinellum and $P$. resedanum (Troncoso et al., 2010 and Khan et al., 2015a,b).

Salinity represented major ecological elements restricting plant development and productivity; it causes huge decrease in the plant development parameters (Hamada and Al-Hakimi, 2002). High groupings of water salinity cause genuine severe yield decreasing, around $20 \%$ of the 
world's developed fields influenced by saltiness as it's in charge of plant cell ions disturbance. Salinity action decreased photosynthesis by shut down the stomata and decreasing carbon dioxide accessibility (Sairam and Tyagi, 2004 and Jacoby et al., 2011). High salinity repress root and shoot development other than the high tension in canalized to the perfect solutes (betaine, trehalose and proline, phytohormone (abscisic, brassinosteroid and gibberellic), proteins (ascorbate peroxidase, glutathione peroxidase and catalase) biosynthesis and has extra negative impacts on the cell energy supply, redox homeostasis, and photosynthesis (Gao et al., 2004; Zhu et al., 2010; Chen and Murata, 2011; Jacoby et al., 2011; Nounjan et al., 2012; Muller et al., 2014; Leitãoa and Enguita, 2016).

Gibberellins have been accounted to advance the plant development (rice seedling) and a few halophytes in saline condition (Kaur et al., 1998 and Dheeba et al., 2015).Salt pressure prompted the repression of the gibberellin pathways signaling performing lower cell cycle which appeared to be essential amid the late periods of the salt reaction to promote recovery (West et al., 2004; Geng et al., 2013; Leitãoa and Enguita, 2016). If we assumed that in 2050 (As per FAO) the number of population will increment 2.3 billion, speaking to an expansion of $70 \%$ of crops production requests another new methodology for threatening the security of worldwide food is basic and essential (FAO, 2009). A maize crop is exceptionally delicate to salinity, germination percentage and rates of corn grains would diminish by expanding salinity concentrations (Maas, 1986). Treatment with gibberellins had no impact on seed germination in wrong concentrations, however when using the write one expanded in shoot length, root length, dry weight, fresh weight and tissue water content occurred (Khan et al., 2010 and Ghodrat \& Rousta, 2012).

The principle goal of this research is to test the capacity of various Fusarium species to produce gibberellic acid on basal medium, furthermore test the application of microbial gibberellins extracted on Zea mays plant under various levels of salinity stress.

\section{Materials and Methods}

\section{Microorganisms and inoculums preparation}

Diverse Fusarium species, isolated from Egyptian clover, garlic, maize and onion plants on potato dextrose agar medium (PDA) at $28 \pm$
$1{ }^{\circ} \mathrm{C}$ with incubation time 7 days were used in this research. Fusarium species were identified based on their macroscopic development on various media and microscopic characteristics under light microscope instrument (Leslie and Summere, 2006).Fresh and pure cultures moved into pure PDA slants and kept up at $4 \pm 1{ }^{\circ} \mathrm{C}$. For inoculums preparation, Fusarium sp. developed on PDA medium at $28 \pm 1{ }^{\circ} \mathrm{C}$ for 7 days. Fungal hyphae scraped from growth plates suspended in sterilized distilled water fortified with $0.01 \%(\mathrm{v} / \mathrm{v})$ tween 80 to avoid spore gathering and stirred for half hour until get $3 \times 10^{5}$ spore/ml (Mahmoud and Mostafa, 2017).

\section{Screening for gibberellin production by Fusarium} sp.

Czapek's dextrose fluid medium was utilized as production medium containing (g/l): glucose, 30.0; yeast extract, 5; $\mathrm{NaNO}_{3}, 3.0 ; \mathrm{KH}_{2} \mathrm{PO}_{4}$, $1.0 ; \mathrm{MgSO}_{4} .7 \mathrm{H}_{2} \mathrm{O}, 0.5 ; \mathrm{KCl}, 0.5, \mathrm{FeSO}_{4} .7 \mathrm{H}_{2} \mathrm{O}$, 0.01 and $1000 \mathrm{ml}$ distilled water with initial $\mathrm{pH}$ regulate to 5.5. After sterilization in an autoclave at $121{ }^{\circ} \mathrm{C}$ for $20 \mathrm{~min}$. chloramphenicol, $250 \mathrm{mg} /$ $\mathrm{ml}$ include independently as bacteriostatic agent sterilized by membrane filtration $(0.22 \mathrm{~mm})$. The cultures incubated at $28 \pm 1{ }^{\circ} \mathrm{C}$ on a rotary shaking $(150 \mathrm{rpm})$ for 7 days. All the experiments were done independently in triplicates (Shahzad et al., 2016).

\section{In vivo application of microbial gibberellin}

Pots experiment was executed in the Experimental Farm of Arab El- Awammer Research Station, ARC, Assiut, Egypt (which, lies between latitude $27^{\circ}, 11^{\prime} \mathrm{N}$ and longitude $31^{\circ}, 06^{\prime}$ $\mathrm{E}$ and the altitude of the area is $71 \mathrm{~m}$ ) to evaluates the impacts of soaking Zea mays grains in five levels of microbial gibberellins extended from 0 to $200 \mathrm{ppm}$ (soaked for 12 hours) under three levels of irrigation water salinity $(500,1500$ and $2500 \mathrm{ppm}$ ). Germination percentage and seedling development (Plant high (cm), Shoot fresh weight (g) and Root weight (g)) of Zea mays (at 20 day age) were assessed. The experiment included 15 treatments with three replicates; all treatments were organized in spilt plots design. Soil physical and chemical properties were estimated and recorded in Table (1).

\section{Analytical analysis}

Fungus mycelia recovered by filtration through dried and weighed Whatman filter paper (No. 113), washed three times with distilled water, dried in oven at $70{ }^{\circ} \mathrm{C}$ overnight for dry mass (DM) estimation. The supernatants were

Egypt. J. Soil Sci. 58, No. 3 (2018) 
centrifuged at 4,000 rpm for $15 \mathrm{~min}$., sterilized by membrane filtration using a membrane of pore size $0.22 \mathrm{~mm}$ to evacuate any residual spores for quantitative estimation of gibberellic acid (GA3).

For gibberellins extraction, culture medium was acidified to $\mathrm{pH} 2.5$ with $\mathrm{HCl}(1 \mathrm{M})$ and extracted using liquid-liquid (ethylacetate/ $\mathrm{NaHCO}_{3}$ ) extraction three times. Extracts were filtrated on filter papers contains sodium sulfate anhydrous to remove any water (Cho et al, 1979). Gibberellic acid in the ethyl acetate phase was measured by UV spectrophotometer at $254 \mathrm{~nm}$ against substrate-free blank using T60 UV with a split beam UV visible spectrophotometer covers a wavelength range of 190-1100 nm (Bruckner and Blechschmidt 1991 and Berrios et al., 2004). The amount of gibberellic acid was calculated from the standard curve $(1-10 \mathrm{mg} / \mathrm{L})$ using slandered gibberellic acid. The concentrate extract was stored at $4 \pm 1{ }^{\circ} \mathrm{C}$ for crystallization.
Thin Layer Chromatography (TLC) was used as confirmation test for the presence of gibberellin. Gibberellic acid dissolved in ethanol and spotted on the silica gel $(\mathrm{SiO} 2)$ plates using mobile phase containing isopropanol: ammonia: water (10:1:1). After the solvent reach to the end line, the plates were removed, sprayed with $3 \%$ sulphuric acid containing $50 \mathrm{mg} \mathrm{FeCl}$ and heated in oven at $80^{\circ} \mathrm{C}$ for $10 \mathrm{~min}$. The gibberellic acid appeared as greenish black spot under UV light (Cavell et al, 1976).

\section{Statistical analysis}

All obtained data were subjected to statistical analysis of varianceand treatment means were compared for significant differences using the LSD at $p=0.05$. The MSTAT-C (version 2.10) computer program was used to perform all the analysis of variance in agreement with the procedure outlined by Steel and Torrie (1982).

TABLE 1. Physical and chemical characteristics of representative composite soil sample from the field experimental site

\begin{tabular}{|c|c|c|c|c|c|c|c|c|c|}
\hline \multicolumn{10}{|c|}{ Chemical properties } \\
\hline \multirow{2}{*}{$\begin{array}{c}\mathrm{pH} \\
(1: 1)\end{array}$} & \multirow{2}{*}{$\begin{array}{c}E C \\
d S / m \\
(1: 1)\end{array}$} & \multicolumn{4}{|c|}{ Soluble cations (meq / L) } & \multicolumn{2}{|c|}{$\begin{array}{l}\text { Soluble anions } \\
\quad(\mathrm{meq} / \mathrm{L})\end{array}$} & \multirow{2}{*}{$\begin{array}{c}\text { Available } \\
\text { Phosphorus } \\
\text { (ppm }\end{array}$} & \multirow{2}{*}{$\begin{array}{c}\text { Total } \\
\text { nitrogen } \\
(\%)\end{array}$} \\
\hline & & $\mathbf{C a}^{++}$ & $\mathbf{M g}^{++}$ & $\mathrm{Na}^{+}$ & $\mathbf{K}^{+}$ & $\begin{array}{c}\mathrm{CO}_{3}^{--} \\
+\mathrm{HCO}_{3}^{-}\end{array}$ & $\mathrm{Cl}$ & & \\
\hline 8.37 & 0.33 & 1.43 & 1.16 & 0.19 & 0.75 & 1.68 & 1.47 & 8.31 & 0.003 \\
\hline \multicolumn{10}{|c|}{ Physical properties } \\
\hline \multicolumn{3}{|c|}{$\begin{array}{l}\text { Particle size distribution } \\
\qquad(\%)\end{array}$} & Texture & \multicolumn{3}{|c|}{$\begin{array}{c}\text { Moisture content (Volumetric } \\
\%)\end{array}$} & O.M & \multirow{2}{*}{$\mathrm{CaCO}_{3}(\%)$} & \multirow{2}{*}{ bulk density } \\
\hline Sand & Silt & Clay & class & S. P. & F.C. & W.P. & $(\%)$ & & \\
\hline 89.9 & 7.1 & 3.0 & sandy & 23.3 & 10.9 & 4.5 & 0.19 & 30.9 & 1.63 \\
\hline
\end{tabular}

\section{Results}

Gibberellic acid production by Fusarium sp.

Seven Fusarium species, obtained from Egyptian clover, garlic, maize and onion plants on PDA medium used in this experiment. A wide variation in gibberellic acid production on the screening medium ranged from 0 to $268.96 .27 \pm$ $\mathrm{mg} / \mathrm{l}$, productivity from 0 to 38.42 and dry mass varied between $2.75 \pm 0.05$ and $9.648 \pm \cdot, 33$ $\mathrm{g} / \mathrm{l}$ as shown in Fig. 1. The highest gibberellic acid producers were Fusarium oxysporum I, F. solani and $F$. oxysporum II giving $268.9 \pm 6.27$, $252.17 \pm 7.29$ and $204.98 \pm 5.437 \mathrm{mg} / \mathrm{l} \mathrm{GA3}$ (with productivity $38.42,36.03$ and $29.28 \mathrm{mg} / \mathrm{l} /$ day) and $9.648 \pm 0.33,7.2 \pm 0.57$ and $8.58 \pm 0.63 \mathrm{~g} / 1$ dry mass, respectively. Brief description of gibberellic acid high producer; Fusarium oxysporum Schlechtendal was performed; growth on potato dextrose agar plates for 7 days showing growth rate $80 \mathrm{~mm}$, with white mycelium and violet undersurface (Fig. 2A \&B). The fungus formed monophialidic and polyphialidic conidiogenous cells (Fig. 2C). Microconidia abundant and oval in shaped, usually not septate microconidia, macroconidia present, curved and septate (Fig. 2D). 


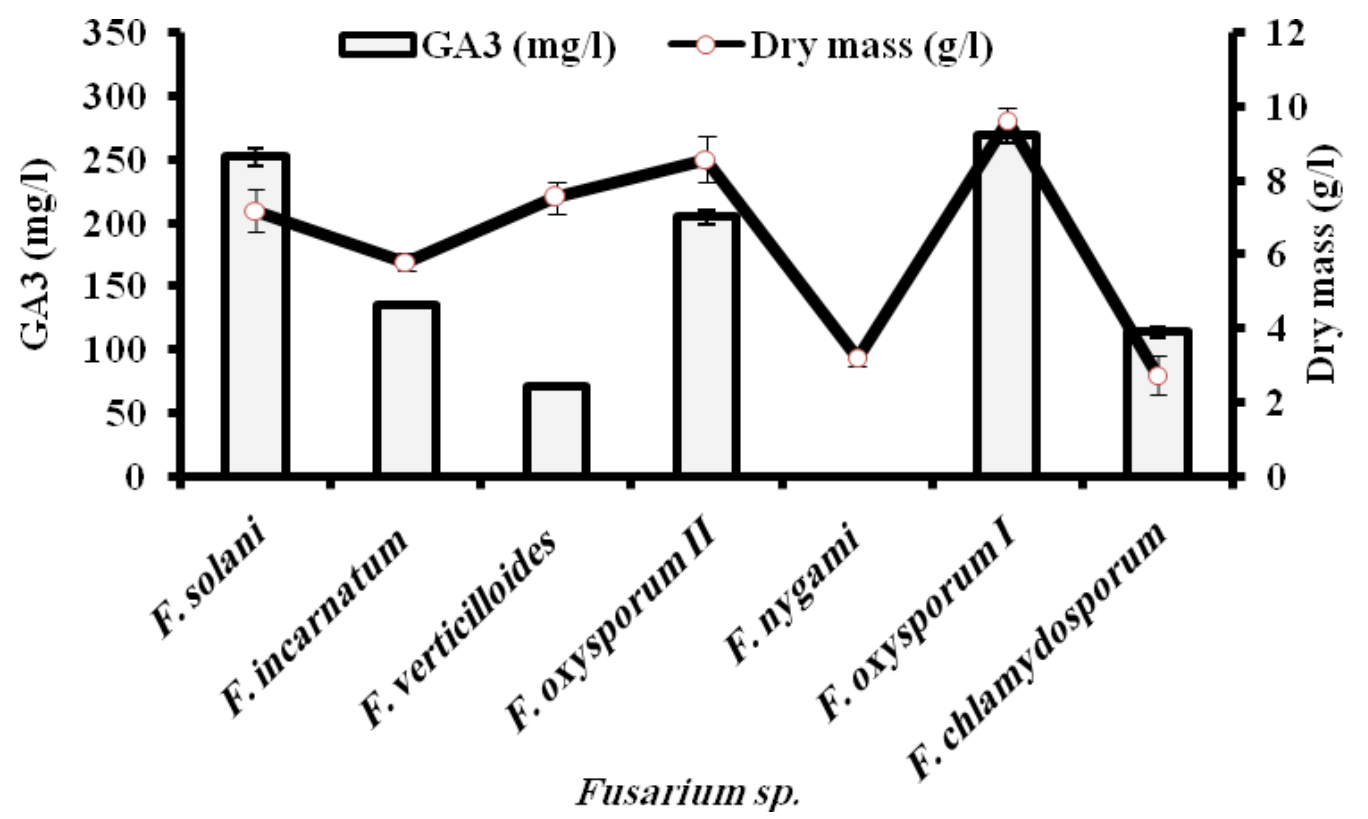

Fig. 1. Screening for GA3 production on Czapek's liquid medium using different isolates of Fusarium sp

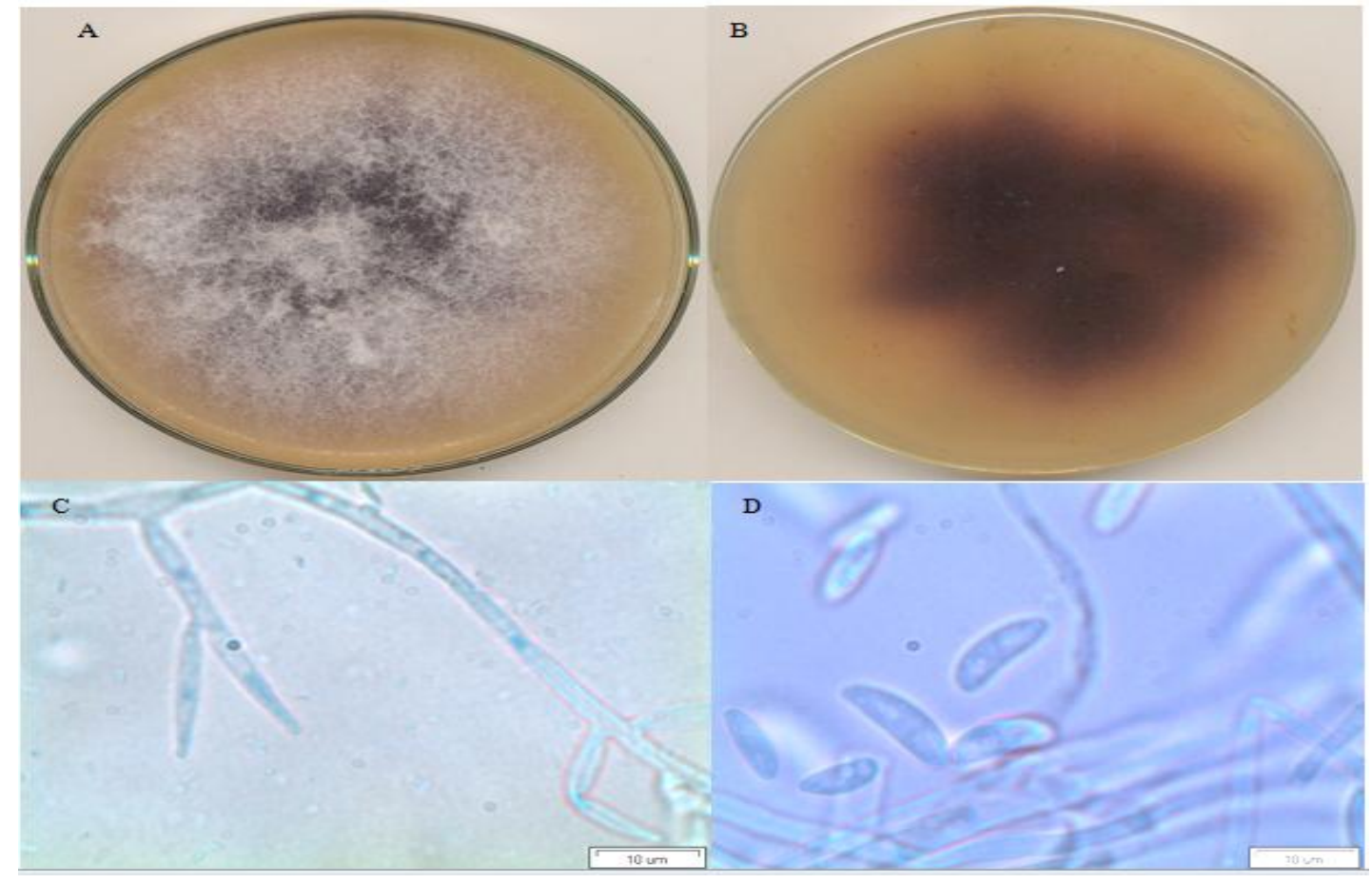

Fig. 2 . Fusarium oxysporum, A, B: Fungus growth on potato dextrose agar medium and its reverse; C:Monophilaidic and polyphilaidic conidiogenous cell;D:Microconidia (Mi) and Macroconidia (Ma); Bars, $10 \mu \mathrm{m}$

In vivo application of gibberellic acid production by Fusarium oxysporum

Data in Fig. 3 - 6 showed the effect of soaking Zea mays grains in five levels of microbial gibberellins ranged from 0-200 ppm under three levels of water salinity (500, 1500 and $2500 \mathrm{ppm})$ on germination percentage and seedling growth (Plant high (cm), Shoot fresh weight $(\mathrm{g})$ and Root weight (g)) of Zea mays (at 20 day age). The results showed that the effect of water salinity on plant high $(\mathrm{cm})$, shoot fresh weight $(\mathrm{g})$, root weight $(\mathrm{g})$ was significant $(\mathrm{p}<0.05)$; however no significant effect observed in germination percentage. The highest values of plant high $(\mathrm{cm})$, shoot fresh weight $(\mathrm{g})$, root weight $(\mathrm{g})$ obtained by irrigation with $500 \mathrm{ppm}$ of salinity water with 
$14 \% 34.9 \%$ and $33.7 \%$ increasing respectively, rather than 2500 ppm salinity water.

The effect of gibberellin concentrations on seedling growth was significant, but was no significant $(p<0.05)$ for germination rate. Soaking grains in $150 \mathrm{ppm}$ gibberellins achieved the highest values of plant high $(\mathrm{cm})$, shoot fresh weight $(\mathrm{g})$ and root weight $(\mathrm{g})$ with $17.5 \% 47.3$ $\%$ and $42.9 \%$ respectively increasing higher than control (zero ppm gibberellins). This might be due to enhancements in cell enlargement and division.

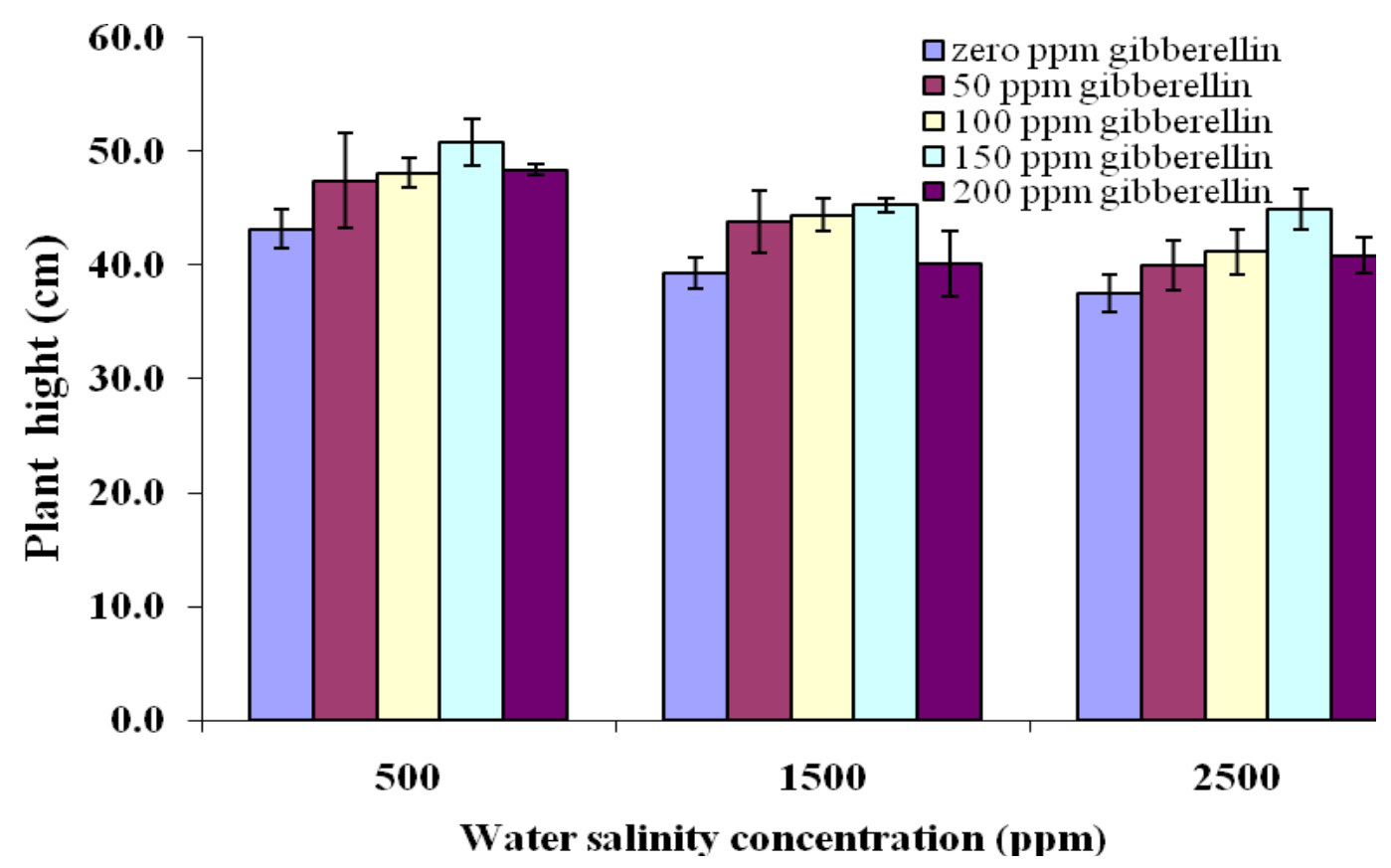

Fig. 3. Plant high (cm) of Zea mays (at 20 day age) as influenced by water salinity concentration levels and soaking grains in different levels of gibberellin

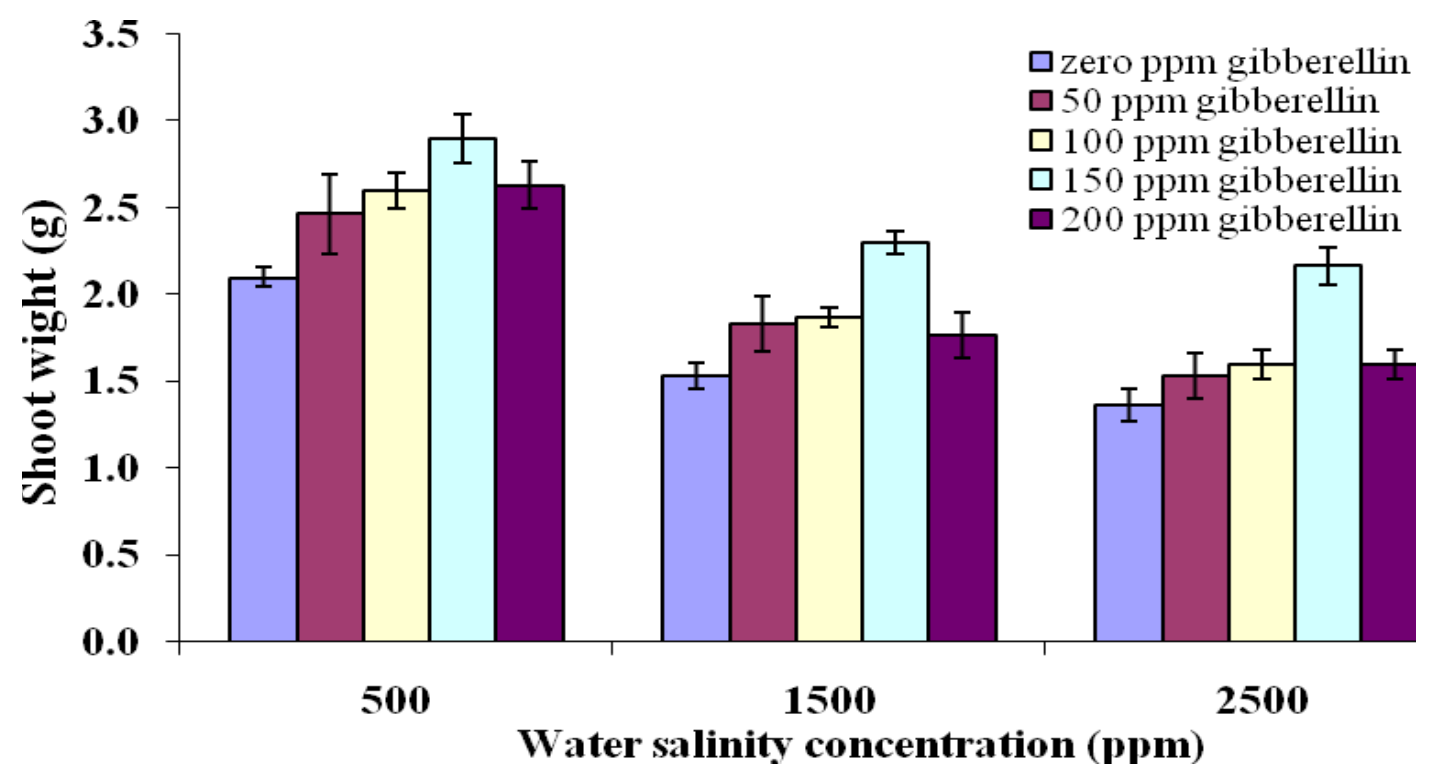

Fig. 4. Shoot fresh weight (g) of Zea mays (at 20 day age) as influenced by water salinity concentration levels and soaking grains in different levels of gibberellin 


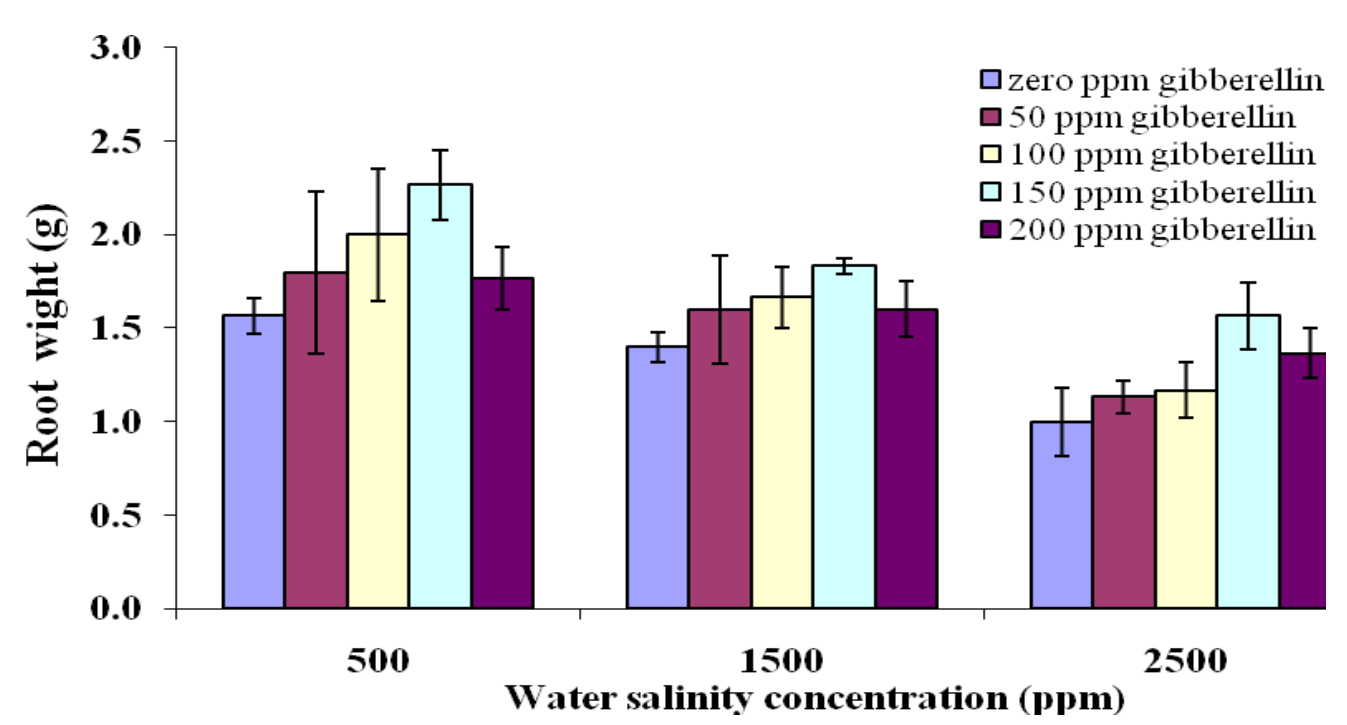

Fig. 5. Root weight (g) of Zea mays (at 20 day age) as influenced by water salinity concentration levels and soaking grains in different levels of gibberellin

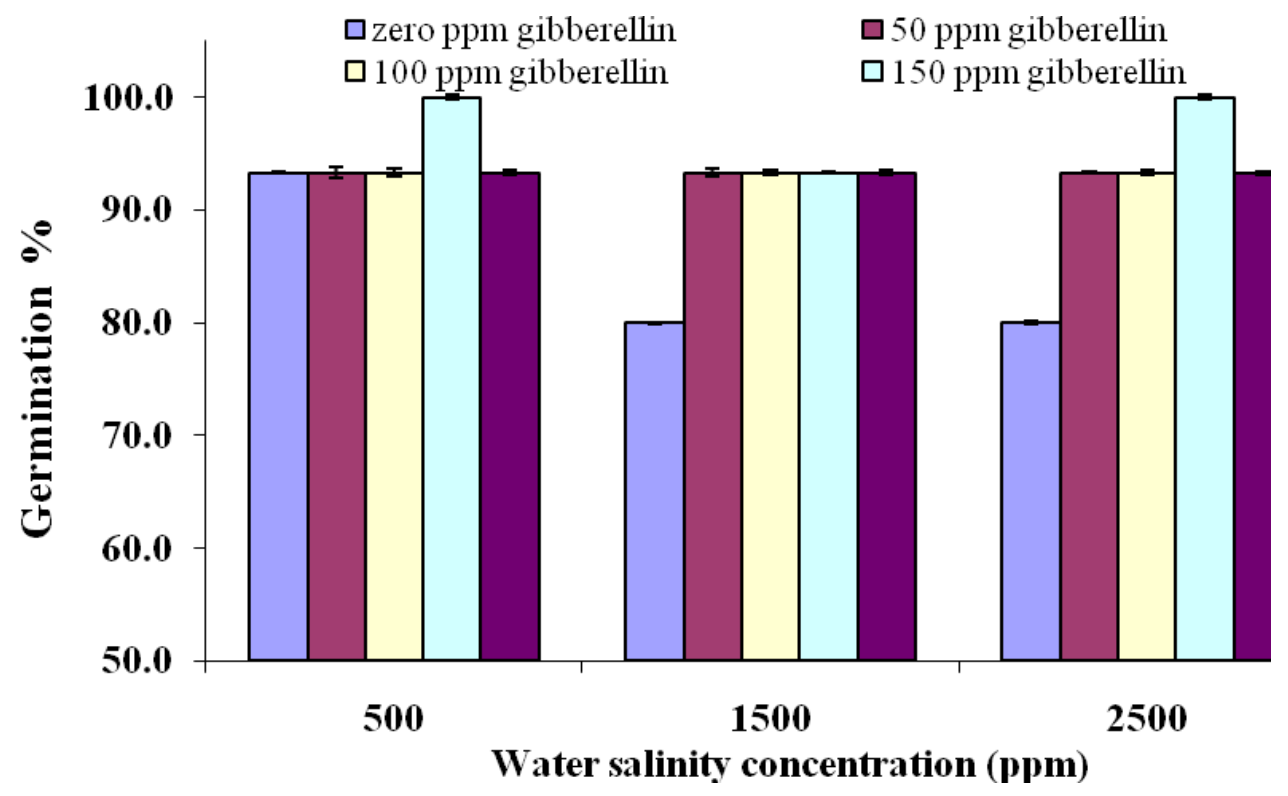

Fig. 6. Germination percentage of Zea mays as influenced by water salinity concentration levels and soaking grains in different levels of gibberellin

The interaction between water salinity and gibberellins concentrations on seedling growth was significant (Fig. 7). The highest synergetic effect of water salinity and gibberellins produced in $500 \mathrm{ppm}$ water salinity and $150 \mathrm{ppm}$ gibberellins. Irrigation with water salinity 2500 ppm with gibberellic acid soaking (150 ppm) chive remarkable increasing plant high and shoot fresh weight comparative with 500 ppm water salinity and zero ppm gibberellins this means the application of gibberellins increasing the tolerance of plant to water salinity during their growing period.

\section{Disscussion}

Fusarium species has a great capacity to produce various amounts of gibberellin as a plant hormone particularly Fusarium oxysporum which considered as a hopeful isolate for microbial gibberellin production with the capacity to apply in vitro and vivo. Several scientists in agreement with our outcomes; Curtis (1957) inferred that 
Gibberella fujikuroi was the microorganism that can produce gibberellins. Sanchez-Marroquin (1963) tested around 43 strains of Fusarium sp. and detailed that $F$. moniliforme could give higher yields of GA3 on variety media. Other fungi additionally produced gibrellins e.g. Fusarium sacchari, Fusarium konzum, Aspergillus fumigatus, and Penicillium resedanum (Troncoso et al., 2010 and Khan et al., 2015 a, b). Jefferys (1970) revealed that the ideal temperature for development of the strain Gibberella fujikuroi is between $31-32{ }^{\circ} \mathrm{C}$ while the production of GA3 was maximized at $29{ }^{\circ} \mathrm{C}$. Shukla et al. (2005) who's discovered that $\mathrm{pH} 5.0$ was the ideal for gibberellic acid production. Meleigy and Khalaf 2009 recorded critical increase of gibberellic acid $\left(2.25 \mathrm{gl}^{-1}\right)$ at $\mathrm{pH} 5$ after 6 days of incubation.

Salinity represents one of major environmental issues in charge of constraining in plant development, productivity and critical decrease in plant weight. Zea mays plant exceptionally delicate to salinity and numerous losses in the crop yield caused because of the stress (Maas, 1986; Hamada and Al-Hakimi, 2002). Ghodrat et al (2013) demonstrated that salinity stress considered as a serious issue cause diminished in plants root, shoot weights as well as germination rate and percentage of Zea mays. Application of GA3 treatment on Zea mays plants indicated increase in the parameters which diminished by salt water stress. Microbial gibberellin raised the plant resistance to salinity stress synergistically with concentration until the most effective concentration of gibberellin $150 \mathrm{ppm}$ (demonstrated the most increasing in shoot fresh weight, dry weight, plant length and roots weight compared to control under the three levels of irrigation water salinity). Gibberellic Acid (GA3) considered as the most essential development regulator promotes germination, hypocotyls development and increases the size of leaves. It stimulates hydrolytic enzymes essential for the degradation of cells around radical resulting speeds in germination (Boucaud and Ungar, 1976; Rood et al., 1990; Hisamatsu et al., 2000 and Tuna et al., 2008). The appropriate concentration of GA assumes an important role in the induction of plant salinity tolerance particularly when applied in environment (Jamil and Rha, 2007; Kaya et al., 2010).Ghodrat and Rousta (2012) test the priming of the corn by GA3 $(0-5 \mathrm{mg} / \mathrm{L})$ and found that it offer resistance to corn under salinity stress. Dheeba et al. (2015) revealed that application of gibberellin takes out the adverse impact of salinity stress on black gram seedlings.
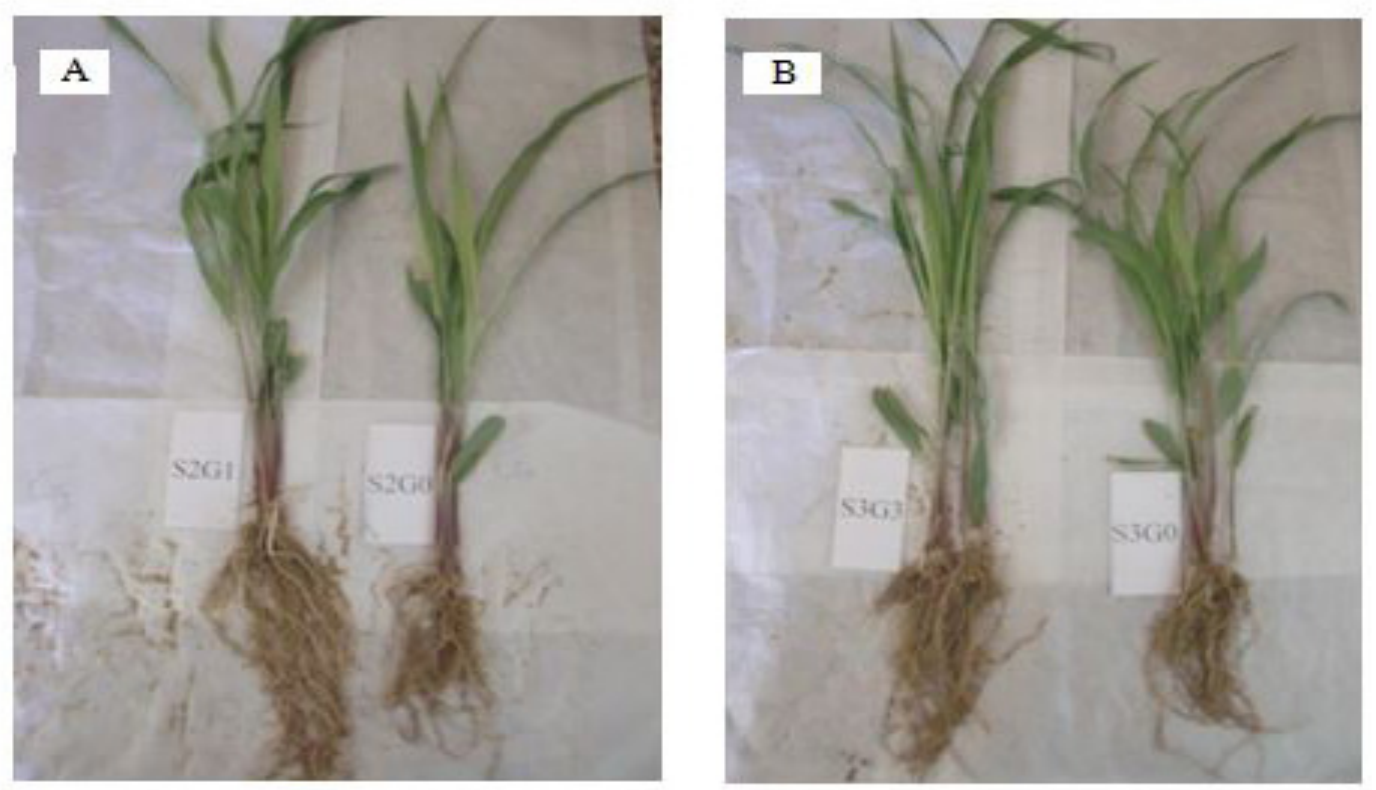

Fig. 7. Impact of microbial gibberellin on germination of Zea mays plant A;Zea mays germination under $1500 \mathrm{ppm}$ water salinity with two levels of gibberellin G1 (50 ppm) and G0 (zero),B;Zea mays germination under $2500 \mathrm{ppm}$ water salinity with two levels of gibberellin G3 (150 ppm) and G0 (zero) 


\section{Conclusion}

Fusarium oxysporum considered as the highest potential gibbrellic acid producer. The fungus has high efficiency to utilize glucose as a carbon source for production of gibbrellic acid. Application of microbial gibberellin proved its ability to enhance Zea mays growth under different levels of water salinity. This application of microbial hormone pointed to the importance of the green technology of phytohormonse instead of chemical once.

\section{References}

Berrios, J., Illanes, A. and Aroca, G. (2004) Spectrophotometric method for determining gibberellic acid in fermentation broths. Biotechnol. Lett. 26, 67-70.

Boucaud, J. and Ungar, I.A. (1976) Hormonal control of germination under saline condition of three halophytic taxa in the genus Suaeda. Physio. Plantarum 37, 143-148.

Bruckner, B. and Blechschmidt, D. (1991) The gibberellin fermentation. Crit. Rev. Biotechnol. 11, 163-192.

Cavell, B.D., MacMillan, J., Pryce, R.J. and Sheppard, A.C. (1967)Thin layer chromatography of gibberellic acid. Phytochem. 6, 867-871.

Chen, T.H. and Murata, N. (2011) Glycinebetaine protects plants against abiotic stress: mechanisms and biotechnological applications. Plant Cell Environ. 34 (1), 1-20.

Cho, K.Y., Sakurai, A., Kamiya, Y.,Takahashi, N. and Tamura, S. (1979) Effects of the new plant growth retardants of quaternary ammonium iodides on gibberellin biosynthesis in Gibberellafujikuroi. Plant Cell Physiol. 20, 25-81.

Cross, B.E., Grove, J.F., MacMillan, J., Moffatt, J.S. and Mulholland, T.P.C. (1959) A revised structure for gibberellic acid. Proc. Chem. Soc., 302-303.

Curtis, R.W. (1957) Translocatable plant growth inhibitors produced by Penicilliumthomii and Arachniotustrisporus. Sci. 125, 646-648.

Davies, P.J. (2004) Kluwer Academic Publishers, Dordrecht, Netherlands, pp.63-94.

Dheeba, B., Selvakumar, S., Kannan, M. and Kannan, K. (2015) Effect of Gibberellic Acid on Black Gram (Vignamungo) Irrigated with Different Levels of Saline Water. RJPBCS. 6 (6), 709-720.

Fahad, S., Hussain, S., Matloob, A. and Khan, F.A.

Egypt. J. Soil Sci. 58, No. 3 (2018)
(2014) Phytohormones and plant responses to salinity stress: a review. Plant Growth Regul.75 (2),391-404.

F.A.O. (2009) High Level Expert Forum-How to Feed the World in 2050. Economic and Social Development. Food and Agricultural Organization of the United Nations, Rome.

Gao, X.P., Pan, Q.H., Li, M.J., Zhang, L.Y., Wang, X.F., Shen, Y.Y., Lu, Y.F., Chen, S.W.,Liang, Z. and Zhang, D.P. (2004) Abscisic acid is involved in the water stress-induced betaine accumulation in pear leaves. Plant Cell Physiol. 45 (6), 742-750.

Geng, Y., Wu, R., Wee, C.W., Xie, F., Wei, X., Chan, P.M., Tham, C., Duan, L. and Dinneny,J.R. (2013) A spatio-temporal understanding of growth regulation during the salt stress response in Arabidopsis. Plant Cell. 25 (6), 2132-2154.

Ghodrat, V. and Rousta, M.J. (2012) Effect of Priming with Gibberellic Acid (GA3) on Germination and Growth of Corn (Zea mays L.) under Saline Conditions, IJACS. 4 (13), 882-885.

Ghodrat, V., Rousta, M.J. andKarampour, A. (2013) Growth analysis of corn (Zea mays L.) as influenced by indole-butyric acid and gibberellic acid. J. Basic Appl. Sci. Res. 3 (2), 180-185.

Hamada, A.M. and Al-Hakimi, A.M.A. (2002) Salicylic acid versus salinity-drought induced stress on wheat seedlings. Rostlinna Vyroba. 47, 444-450.

Hedden, P., Phillips, A.L., Rojas, M.C., Carrera, E. and Tudzynski, B. (2001) Gibberellin biosynthesis in plants and fungi: a case of convergent evolution. $J$. Plant Growth Regul. 20 (4), 319-331.

Hisamatsu, T., Koshioka, M., Kubota, S., Fujime, Y., King, R.W. andMander, L.N. (2000) The role of gibberellin in the control of growth and flowering in Matthiolaincana. Physio. Plantarum. 109, $97-$ 105.

Hussain, S., Peng, S., Fahad, S.and Khaliq, A. (2014) Rice management interventions to mitigate greenhouse gas emissions: a review. Environ Sci. Pollut. Res. 22 (5), 3342-3360.

Jacoby, R.P., Taylor, N.L. and Millar, A.H. (2011) The role of mitochondrial respiration in salinity tolerance. Trends Plant Sci. 16 (11), 614-623.

Jamil, M.E. andRha, S. (2007) Gibberellic acid (GA3) enhances seed water uptake, germination and early seedling growth in sugar beet under salt stress. PakistanJ. Bio. Sci. 10 (4),654-658. 
Jefferys, E.G. (1970) The gibberellin fermentation. Adv. Applied Microbiol. 13, 283-316.

Kaur, S., Gupta, A.K.and Kaur, N. (1998) Gibberellin A3 reverses the effect of salt stress in chickpea (Cicerarietinum L.) seedlings by enhancing amylase activity and mobilization of starch in cotyledons. Plant Growth Reg. 26, 85-90.

Kaya, C., Tuna, A.L. andOkant,A.M. (2010) Effect of foliar applied kinetin and indole acetic acid on maize plants grown under saline conditions, Turk $J$. Agric. 34, 529-538.

Khan, A.L., Hussain, J., Al-Harrasi, A., Al-Rawahi, A. and Lee, I.J. (2015 a) Endophytic fungi: resource for gibberellins and crop abiotic stress resistance. Crit. Rev. Biotechnol. 35 (1), 62-74.

Khan, A.L., Waqas, M. and Lee, I.J. (2015 b) Resilience of Penicilliumresedanum LK6 and exogenous gibberellin in improving Capsicumannuum growth under abiotic stresses. J. Plant. Res. 128 (2), 259-268.

Khan, M.N., Siddiqui, M.H., Mohammad, F., Naeem, M. and Khan, M.M.A. (2010) Calcium chloride and gibberellic acid protect linseed (Linumusitatissimum L.) from $\mathrm{NaCl}$ stress by inducing antioxidativedefence system and osmoprotectant accumulation. Acta Physiol. Plant 32 (1), 121-132.

Leitãoa, A.L. andEnguita, F.J. (2016) Gibberellins in Penicillium strains: Challenges for endophyteplant host interactions under salinity stress. Microbiological Res. 183, 8-18.

Leslie, J.F. andSummerell, B.A.(2006) The Fusarium Laboratory Manual. Blackwell Publishing.

Maas, E.V. (1986) Salt tolerance of plants. Appl. Agric. Res. 1, 12-25.

Mahmoud, G.A.E.,Mostafa, H.H.A. (2017) Statistical optimization as a powerful tool for indole acetic acid production by Fusariumoxysporum. Euro. J. Biol. Res. 7 (4), 315-323.

Meleigy, S.A. and Khalaf, M.A. (2009) Biosynthesis of gibberellic acid from milk permeate in repeated batch operation by a mutant Fusariummoniliforme cells immobilized on loofa sponge. Bioresource Technol. 100, 374-379.

Muller, M., Kunz, H.H., Schroeder, J.I., Kemp, G., Young, H.S. andNeuhaus, H.E. (2014) Decreased capacity for sodium export out of Arabidopsis chloroplasts impairssalt tolerance, photosynthesis and plant performance. Plant J. 78 (4), 646-658.
Nounjan, N., Nghia, P.T. andTheerakulpisut, P. (2012) Exogenous proline and trehalose promote recovery of rice seedlings from salt-stress and differentially modulate antioxidant enzymes and expression of related genes. J. Plant Physiol. 169 (6),596-604.

Olszewski, N., Sun, T.P. and Gubler, F. (2002) Gibberellin signaling: biosynthesis, catabolism, and response pathways. Plant Cell, 14, 61-80.

Quang, T.H., Ngan, N.T., Ko,W., Kim, D.C., Yoon, C.S., Sohn, J.H., Yim, J.H., Kim, Y.C. and Oh, H. (2014) Tanzawaic acid derivatives from a marine isolate of Penicillium sp. (SF-6013) with antiinflammatory and PTP1B inhibitory activities. Bio. Med.Chem.Lett. 24 (24), 5787-5791.

Rood, S.B., Buzzell, R.I., Major, D.J. and Pharis, R.P. (1990) Gibberellins and heterosis in maize: quantitative relationship. Crop Sci. 30, 281-6.

Sairam, R.K. andTyagi, A. (2004) Physiology and molecular biology of salinity stress tolerance in plants. Curr. Sci. 86, 407-421.

Sanchez-Marroquin, A. (1963) Microbiological production of gibberellic acid in glucose medium. Appl. Microbiol. 11, 523-528.

Shahzad, R., Waqas, M., Khan, A.L., Asaf, S., Khan, M.A., Kang, S.M., Yun, B.W. and Lee, I.J. (2016) Seed-borne endophyticBacillus amyloliquefaciens RWL-1 produces gibberellins and regulates endogenous phytohormones of Oryza sativa. Plant Physio.Biochem. 106, 236-243.

Shukla, R., Chand, S. and Srivastava, A.K. (2005) Improvement of gibberellic acid production using a model based fed-batch cultivation of Gibberella fujikuori. Proc.Biochem. 40, 2045-2050.

Steel, R.G.D. and Torrie, J.H. (1982) Principals and Procedures of Statistics. A Biometrical Approach. McGraw Hill Book Company, New York. USA

Tansakul, C., Rukachaisirikul, V., Maha, A., Kongprapan, T., Phongpaichit, S., HutadilokTowatana, N., Borwornwiriyapan, K. and Sakayaroj, J. (2014) A new phenalenone derivative from the soil fungus Penicilliumherquei PSURSPG93. Nat. Prod. Res. 28 (20), 1718-1724.

Troncoso, C., Gonzalez, X., Bomke, C., Tudzynski, B., Gong, F., Hedden, P. and Rojas,M.C. (2010) Gibberellin biosynthesis and gibberellin oxidase activities in Fusariumsacchari, Fusariumkonzum and Fusariumsubglutinans strains. Phytochem. 71 (11-12), 1322-1331. 
Tuna, A.L., Kaya, C., Dikilitas, M. and Higgs, D. (2008) The combined effects of gibberellic acid and salinity on some antioxidant enzyme activities, plant growth parameters and nutritional status in maize plants. Environ.Experl. Bot. 62 (1), 1-9.

West, G., Inze, D. andBeemster, G.T. (2004) Cell cycle modulation in the response of the primary root of Arabidopsis to salt stress. Plant Physiol. 135 (2), 1050-1058.

Wu, Z.H., Wang, T.H., Huang, W. andQu, Y.B.(2001) A simplified method for chromosome DNA preparation from filamentous fungi. Mycosystema. 20, 575-577.

Zhu, J., Lee, B.H., Dellinger, M., Cui, X., Zhang, C., Wu,S., Nothnagel, E.A. and Zhu, J.K. (2010) A cellulose synthase-like protein is required for osmotic stress tolerance in Arabidopsis. Plant J. 63 (1), 128-140.

\section{تأثير الجبرلين الميكروبي علي نباتات الذرة الشامية تحث تأثير مستويات مختلفة من ملحية

يحتل إستخدام التكنولوجيا الخضر اء في الوقت الحاضر لإنتاج الهرمونات النباتية مكانآ هاماً في الإنتاج

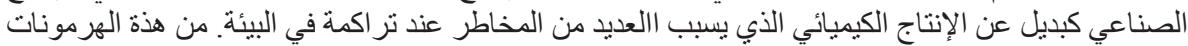

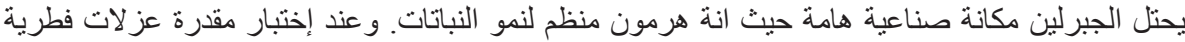

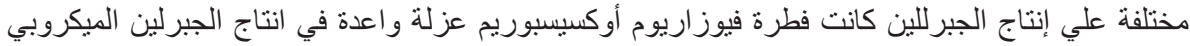

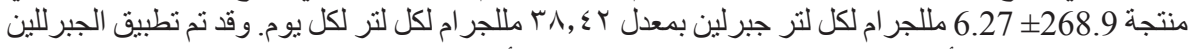

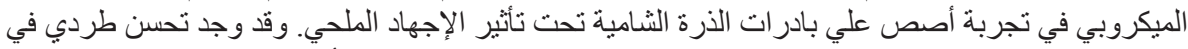

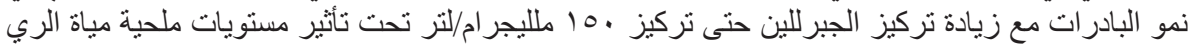

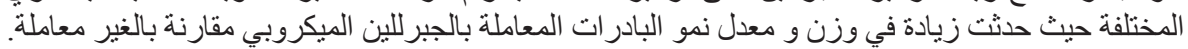

